I Instituto de Investigaciones en Estudios de Género (IIEG),

Comisión Nacional de Investigaciones Cientificas y Estúdios

Técnicos (CONICET), Buenos Aires, Argentina

alejandra.josiowicz@gmail.com

https://orcid.org/oooo-0002-3525-1833

I I Fundação Oswaldo Cruz (Fiocruz), Casa de Oswaldo Cruz (COC),

Programa de Pós-Graduação em História das Ciências da Saúde

Alejandra Josiowicz'

(PPGHCS), Rio de Janeiro, RJ, Brasil

chormaio@gmail.com

https://orcid.org/o0oo-0002-5938-5705

\title{
STEFAN ZWEIG IN EXILE: A COSMOPOLITAN CITIZEN'S INTERPRETATION OF BRAZIL ${ }^{1}$
}

Brazil, land of the future ${ }^{2}$ was born under the sign of political and intellectual controversies. The criticisms oscillated between the disinformation and fragility of the arguments developed in the work to an agreement reached by Stefan Zweig with Getúlio Vargas's Estado Novo, inspired by the Austrian writer's desperate pragmatism in search of exile on Brazilian soil with the advance of Nazism and the Vargas regime's restrictive immigration policy. Zweig's interpretation of Brazil was seen as a jingoistic, naive manifesto, another portrait of the supposed Brazilian natural and racial paradise, images that were widespread in the Brazilian social thought of his time. Other objections to Zweig included his limited knowledge of Brazilian society. According to his critics, it was enough to underscore the absence of classics like Casa-grande \& senzala by Gilberto Freyre (I933) or Raízes do Brasil by Sérgio Buarque de Holanda (I936) in the Austrian author's work. Zweig's Brazilian intellectual circle was limited to the likes of Afrânio Peixoto, the author of the book's preface, a lettered man, physician and hygienist whose academic prestige and recognition was in decline at the beginning of the I940s. Thus, Zweig had no contact with the dense and diverse world of Brazilian essayism. ${ }^{3}$

This article follows a different path by distancing itself from the established criticisms of the book Brazil, land of the future. We believe that the analysis of Zweig's work demands a more nuanced perspective to better situate its historical significance. It was gestated amid diverse experiences like exile, being a refugee, being a Jew who dialogues permanently with his culture of origin 
in a European setting devastated by Nazism and the destruction of a civilizational process. We also seek to highlight the connections that link the book, simultaneously, to the Brazilian, North American and European intellectual contexts, as well as to writing on exile, travel and cosmopolitanism (Spitzer, 200I). Brazil, land of the future contains a tense dialogue, full of failed encounters, between Zweig and the Brazilian milieu: between the author's cosmopolitan and multilingual horizon, the impossibility of belonging and his constant feeling of maladjustment. Zweig questions the European and North American preconceptions concerning the country - at the same time as he reproduces them - and tries to insert Brazil in the cosmopolitan and transnational horizon. Brazil is the space of exile, but also of travel and transformation, an encounter and confrontation with alterity. We also conceive Brazil, land of the future as another manifesto of the I930s and I940s anti-racist agenda, the product of crossdialogues that were not limited to the social reflection on Brazil, but encompassed an international intellectual and political agenda that was continually discussed and disseminated in the United States and Europe and that approached Brazil as a field of experimentation (the "Brazil Experiment," in Zweig's expression), as well as of certifying and positivizing human relations.

Stefan Zweig (I88I-I942) was a famous Jewish Austrian writer of novellas, novels and historical biographies. He watched with horror the outbreak of the First World War and, following the arrival of Hitler to power in Germany and the pro-Nazi climate in Austria, moved to London in I934, subsequently obtaining British citizenship. His books - translated and sold worldwide - were burnt in 1933 by the Nazis and the German publishers were no longer able to print them. He landed in Brazil for the first time in I936, en route to Argentina to take part in a meeting of the International PEN club Association. As a result of this first voyage, he wrote the account Kleine Reise nach Brasilien (A short journey to Brazil), published for the first time in 1936, with his initial observations from the voyage and the fundamental proposals of the future book. In I940, he returned to Latin America for a lecture tour and travelled through Brazil, Argentina and Uruguay, stopping over in Salvador, Recife and Belém. As a result of his second trip, he wrote Brazil, land of the future, which would be published the following year. In I94I, after acquiring a permanent visa, he moved to Petrópolis. He committed suicide in 1942 with his wife, Charlotte Altmann (Dines, 2004).

In recent decades, Zweig has been recuperated as a central figure to understanding the challenges of the twenty-first century. Specifically, his essay Brazil, land of the future and his relation to the country have come under the scrutiny of cultural historians and literary critics. Alberto Dines (2004) wrote one of the most systematic studies on Zweig's relation to Brazil, arguing that for him the country constituted a possible space for taking in Jewish refugees. Leo Spitzer (200I), for his part, examines the figure of Zweig as a humanist and 
internationalist Jew, his lack of identification with Zionism and his discomfort with rigid definitions of identity, whether national or political. According to Spitzer, Judaism for Zweig was never a community of belonging, but a mark imposed from outside, given by the experience of persecution. The essay by Mónica Grin (2002), on the other hand, analyses Zweig's suicide through his unease with nationalism and racialism, as a practice of resistance also symbolized by miscegenated Brazilianness. Raul Antelo (2009), in his study, pointed to Zweig's convergence and divergences with Brazilian modernism, emphasizing the modernists' distanced attitude when he died. In a brief text, Sandra Pesavento (200I) reads the book as an account of an estranged traveller, who saw Brazil's otherness from a European reference point, but who inverts its logic of comprehending the real by setting out from the multiple and the not necessarily normalized. Karen Macknow Lisboa (20I I and 20I4), for her part, draws comparisons with other reports by German travellers to Brazil, and underscores the Eurocentric vision of the book, in which Europe remains hegemonic and Brazil remains dependent on the modernizing drive of the European German immigrant, whose contribution proves central (Lisboa, 20 I I: 289). Indeed even when the book displays a degree of criticism of Europe, the Eurocentric and Germanophile continues to predominate in the author's reading of Zweig. By contrast, Afrânio Garcia Jr. (20I I) reads the eulogy to Brazilian miscegenation in Zweig as a way of developing a humanitarian, pacific culture without questioning the correlated social conditions of this peace. Garcia emphasizes that, a defender of the artist's autonomy and of internationalism, Zweig found himself accused of being a nationalist and criticized as apolitical.

In dialogue with these readings, this article analyses the book from a double perspective: as travel writing and an interpretation of Brazil, and at the same time as a text on exile and on cosmopolitanism. Between voyage and exile, the nation and the transnational sphere, the hypothesis is that Zweig creates an interpretation of the country that, without abandoning ethnocentrism, questions the Eurocentric gaze and discovers a potentiality in Brazil, a possible future thought from the periphery. For Zweig, Brazil's potency resides not so much in its economic or political development, but in the potential creation of a multiple sociocultural horizon, which he, with poetic ingenuity, believes to have seen in Brazil.

\section{THE DIALOGUES OF STEFAN ZWEIG: BETWEEN BRAZIL, THE USA AND EUROPE}

There is a passage in Brazil, land of the future that illustrates the scenario of discussions on race, society and culture in which the book proposes to intervene:

For four hundred years now the masses have been boiling and fermenting in the enormous retort of this country - new material constantly being added, and the mixture being constantly shaken up. Is this process now definitely finished? 
Have these millions already taken form and shape of their own? Is there in existence today something one could call the Brazilian race, the Brazilian man, the Brazilian soul? (Zweig, I94I: I25).

Zweig's questioning condenses the challenges that afflicted the Brazilian intelligentsia from the second half of the nineteenth century, driven by a constant and obsessive endeavour of self-reflection on the country and the problems in defining it as a modern nation. Albeit not without ambiguities, the positive character of the "racial mixture" came to be valorised from the I930s on, especially by Vargas's Estado Novo as part of its affirmation of a mixed national identity. The anthropologist Roquette-Pinto (I929) alerted at the end of the Ig20s that it was not a question of substituting the existing people by bringing thousands of white immigrants, but of valorising the miscegenated profile of the Brazilian population. The theme of miscegenation was recurrent among Brazilian intellectuals like Francisco José Oliveira Vianna and Gilberto Freyre.

In the I930s, Oliveira Vianna was at the centre of the formulation of the social and labour policies of the Vargas government. Although he shared the ideology of whitening, he believed in the idea of process, history and the evolution of society (Guerreiro Ramos, I954). In his studies, Vianna argued that the Brazilian people were in a process of formation. His book Raça e assimilação (I932) (Race and assimilation) advocates the use of scientific discourse as a foundation for mapping racial differences and, principally, establishing a public policy for immigration control in response to the dynamics of Brazilian miscegenation. The ideal point of mixture demanded, according to Oliveira Vianna, a particular rate of assimilation of immigrants that would not endanger the constitution of the Brazilian people. As for the Jews, he diagnosed the existence of a "zero degree of fusibility." He recognized that miscegenation was a given and sought to define the principles that should regulate the dynamics of state action towards the whitening of Brazilian society with desirable immigrants of Iberian extraction (Oliveira Vianna, I959; Ramos, 2003; Maio, I999a; Skidmore, I993).

Zweig alternates between the valorisation of whitening, regarding the European immigration under way then for at least five decades positively, an indicator of civilization (Lisboa, 20I I: 287), and the country as an experiment, as an "art of contrasts," a racial mixture, shifting closer to Gilberto Freyre. In his dialectical perspective of "antagonisms in equilibrium," the extreme violence in the relations between whites and blacks produced by the slave-based plantation monoculture, Freyre emphasizes the idea prevalent in Casa-grande \& senzala of a fraternization between the races, sealed by miscegenation, as the distinctive hallmark of Brazilian society (Freyre, I933; Araújo, I994).

Zweig's narrative also recalls the views of Rüdiger Bilden, a German historian based in the United States, a scholar of Brazilian society who exerted 
a significant influence on Gilberto Freyre. A professor of Fisk University, Nashville, in the I930s, a black college in the south of the United States, Bilden was author of the article "Brazil: a laboratory of civilization," published in the prestigious magazine The Nation, in I929. In this text, he emphasizes the importance of the Portuguese heritage in Brazil's social formation, especially in the development of ethnic-racial relations that enabled intense miscegenation. In characterizing Brazil as a laboratory of civilization, Bilden's article condenses a predominantly harmonious social imaginary of the country shared by various North American and European social scientists between the I930s and I940s, including Robert Park, Franklin Frazier, Melville Herskovits, Donald Pierson, Lorenzo Turner, Otto Klineberg, Ruth Landes, Roger Bastide and Franz Boas (Palhares-Burke, 20I2; Valladares, 20I0; Maio \& Lopes, 20I7; Sansone, 20I I). Brazil is a field of experimentation, a field of positive racial and cultural interactions, including the ideas of testing, processing, mixing and forming a national identity. The 'laboratory' is a metaphor of Brazilianness translated by Stefan Zweig as the "Brazil Experiment" (I94I: 20). This becomes evident in the chapter "Art of Contrasts." In the author's words:

In the streets one runs across many different races: the black Negro from the Senegal in his torn shirt, the European in his smart suit, the Indios with their heavy eyes and jet-black hair; and there are even more complicated breeds of all nations and peoples which cannot be properly defined; but not, as in New York and other cities, living in separate quarters. For in Rio all these people live serenely together, and through the enormous variety of faces the streets form a constantly changing scene. What an art to be able to ease the tensions without destroying them, to preserve this variety without trying to organize it by force! (Zweig, I94I: 280).

Brazilian society revealed a capacity to balance contrasts. Brazil, land of the future also represented a critique of the racialist theories then circulating in Europe and the United States. The critical judgments were further expounded in his Autobiography where Zweig compares living conditions in Brazil and Europe:

People [in Brazil] lived more peacefully, more courteously, the relations between even the most diverse races were not as hostile as among us. [In Europe] man was separated from man by absurd theories of blood and origin; there one could still - and this I perceived with a strange presentiment - live in peace; there space existed for the future in an incommensurable abundance, while in Europe the nations fought and the politicians disputed the most miserable scraps. There the soil still awaited man to take advantage and fill it with his presence. What Europe created in terms of civilization could continue to be developed grandiosely in new and different forms. With my eyes delighted by the multifaceted beauty of this new nature, I looked into the future (Zweig, 20I4b: 296).

Zweig summarizes the argument that would later inform the eulogy realized in Brazil, land of the future. According to his view, racial theories did not influence local thought, differently from the European case. Moreover, the 
paradisiacal vision of the land as an immense, uninhabited territory was a recurrent feature of the national imaginary, which led to an envisioning (Carvalho, I998) of the persecuted migrants from Europe as subjects capable of developing a civilization born in the Northern Hemisphere.

The book also offers the chance to think about particular affinities. The Afro-American sociologist Franklin Frazier, professor of Howard University, the most important black university in the United States at that time, arrived in Salvador in I94I to develop a research project on race relations in Salvador (Frazier, I942). His enchantment with Bahia is no different to that presented by Zweig's book, also released in I94I. Miscegenation and racial integration were aspects of Brazilian society that called the attention of black and Jewish foreign intellectuals who influenced each other. These sociological and anthropological phenomena, portraits of Brazil, were incorporated into the anti-racist agenda of international organizations and black social movements in Brazil and the United States between the I930s and I950s, serving as an instrument to denounce racism and to fight for civil rights (Skidmore, I993; Hellwig, I992).

The idea of a civilization in deep crisis that could be revitalized by social experiences from the periphery of the modern capitalist world, as can be observed in Stefan Zweig's account, was also present in the period after the Second World War. In I945, under the ashes of the Holocaust, UNESCO (United Nations Educational, Scientific and Cultural Organization) was created on European soil with its headquarters in Paris. One of the first policy initiatives to combat racism adopted by the international organisation was to conduct a wide-ranging research project on race relations in Brazil, which continued to be seen as a laboratory, an experiment with civilizational lessons to offer the western world, as Zweig believed. The coordinator of the research project was the Jewish Swiss-American anthropologist Alfred Métraux, who performed an important role in the constitution of the field of human rights in international institutions during the post-war period (Maio, I999b; Krebs, 2016).

Like hundreds of American social scientists, Métraux served in US intelligence agencies during the Second World War. He was in the theatre of operations of the war in Europe as part of the Morale Division, a body linked to the US Strategic Bombing Survey (USSB) responsible for evaluating the impact of the destruction caused by bombing raids by the Allied Forced in Germany and, subsequently, in Japan. He witnessed the liberation of the survivors of Auschwitz. The Holocaust had a significant impact on Alfred Métraux's professional trajectory. On May I8, I945, he wrote a letter to his then wife, the anthropologist Rhoda Métraux, from Tübingen, Germany, describing the dramatic situation:

This afternoon I have been deeply shaken by the sight of a group of Jewish girls who were coming back from one of the death factories - Auschwitz. How to describe them? Imagine corpses who had emerged from the grave. There was around these ambulating skeletons something out of this world. A woman whom 
I thought to be about 50 years old turned out to be 23. As she collapsed and was obviously dying, she was taken away in a hurry. I talked with the others. No sooner one of them began to mention the horrors of the camp, the others started to cry and the girl became hysterical (Métraux quoted in Krebs, 2016: 29).

Métraux continues: "The experiences of this trip [to Germany] have a deep effect on me. It will be difficult to return to library work and the S.A. Indians".

Métraux coordinated a study circle on race relations in Brazil that united a transatlantic network of Brazilian, American and French anthropologists, sociologists and psychologists sponsored by UNESCO. In an article published in the Correio, a science magazine produced by the UN organization, called "Brazil: land of harmony for all races" (I95I) - echoing Brazil, land of the future, the title of Zweig's book in the United States - Métraux conceives Bahia as a miscegenated land that was creating a "new race" on the Latin American continent. Intense miscegenation, the anthropologist wrote, generates an absence of concern over the definition of racial identities. Problems are social rather than racial in nature, which prevailed in accordance with the perspective dominant in the social sciences of the era (Métraux, I95I: 3).

The idea of a "new [Brazilian] race," the outcome of miscegenation, accompanied some of the studies carried out by UNESCO, especially in Bahia. Such is the case of the investigation conducted by the anthropologist Thales de Azevedo, professor of the Faculty of Philosophy of Bahia. In his words: "Stefan Zweig, in a book that was translated in diverse languages, provides a striking description of Bahia and its still living traditions, claiming that it 'was with this town that Brazil - and one can legitimately say South America itself - began. Here was erected the first pillar of the great cultural bridge spanning the ocean. It was here - from European, African, and American substance - that the new still-fermenting mixture came into existence'" (Zweig, I94I: 2I3, quoted in Azevedo, I955). Métraux's vision aligns with Zweig's when it comes to the image of Brazil as a miscegenated country, where a new race was in a constant process of formation. The questioning of Stefan Zweig, who saw his civilization perverted by Nazism, already contain within itself the belief that Brazil represented the new, an absence of races.

\section{ZWEIG: COSMOPOLITAN AND EXILED}

Zweig's cosmopolitanism should be understood in relation to his pacificism and his opposition to the nationalism, racism and xenophobia that he considered responsible for the internecine European wars of the first half of the twentieth century. Zweig thought like a citizen of the world, on the basis of an internationalist notion of identity, correlated to the flourishing of cosmopolitanism in the twentieth century when the economic and political interconnection of peoples, as well as transport and communication technologies, enabled distant communities to come into contact (Robbins \& Horta, 2017; Fontanals Garcia, 2013). 
On the other hand, the idea that Brazil was a new starting point from which the global dilemmas of the twentieth century could be rethought was closely linked to the status of Brazil, land of the future as a travel report, a text on exile and the contradictions of cosmopolitanism. The book concerns the tense and divergent dialogue between Zweig and Brazilian intellectuals, above all between the author's effort to think in cosmopolitan terms, within the "spiritual unity of the world" - the title of one of the lectures he gave in 1936 in Rio de Janeiro and Buenos Aires (Zweig, 20I4a) - and a national and international context traversed by divisions of every kind. This divergence is evident in various areas, one of them being language, a central theme for the exiled intellectual. Written originally in German, Zweig's maternal language, the book was translated and published simultaneously in Portuguese, English, German, Swedish, French and Spanish. Although it was a best-seller in Brazil in the years after its release (it sold I00,000 copies over this time) (Dines, 2004) and indeed internationally, it was received extremely badly by the Brazilian intelligentsia. As the history of its publication reveals, the book was inscribed within an internationalist horizon and its insertion in the Brazilian intellectual environment was full of tensions. Thus, in the aforementioned lecture, Zweig affirms:

Another idealism, one that does not stare at the borders of countries as though hypnotized, an idealism uncontaminated by ancient rancours and sentimental memories - only it can help reconstruct the old Tower of Babel, humankind's solidarity, and all our hope is directed towards you, peoples still with the freshness of youth, who live for the future and not the past with its obsolete ideas (Zweig, 2014a: 28).

In contrast to the nationalist fervour, the idealist horizon of Stefan Zweig, cosmopolitan and multilingual, was embodied in the metaphor of the Tower of Babel: in the Biblical story, the tower represents the human project to attain unity among languages and peoples, with the potential to reach the heavens. But the project is interrupted by divine intervention, which creates the differences between human beings and their languages. Interestingly, although he situates the countries of South America as protagonists of this cosmopolitan horizon embodied in the Tower of Babel, Zweig experienced, in his own skin, the difficulties of dealing with the diversity that appears in the Biblical narrative. Zweig experienced a tense, uncomfortable relationship with the Portuguese language: he had problems adapting to Portuguese, a language that he and his wife, Lotte Zweig, studied and eventually understood, but which they did not like. ${ }^{4}$ Furthermore, one of the recurrent topics in Brazil, land of the future is the lack, on Zweig's part, of a detailed knowledge of the country - "What do I know about Brazil?" (Dines, 2004) he exclaimed - which can be read as one more symptom of his discomfort in his relationship with Brazil.

In her essay on Zweig's autobiography, Hannah Arendt (2007: 318) calls attention to one of the potential causes of this tension between the European intel- 
lectual and the Latin American country: "He considered it unbearably humiliating when the hitherto wealthy and respected citizens of Vienna had to go begging for visas to countries which only a few weeks before they would have been unable to find on a map." As Arendt asserts, his was the Eurocentric perspective of the Viennese citizen, cultured and European, who felt humiliated asking for refuge in an unknown and apparently insignificant country like Brazil. Was Stefan Zweig capable of moving beyond his Eurocentric view of Brazil, meeting the Latin American country halfway? Brazil, land of the future is marked by the tensions between Zweig's cosmopolitan horizon and his difficulty perceiving the Brazilian difference, between a multilingual "unity of the world" and incomprehension in the face of alterity: written in another language on a society and a culture that he saw with the eyes of the expatriate and who saw him as a stranger too.

As Peter Burke (2017) argues in his book Exiles and expatriates in the history of knowledge, the encounter between the exiled intellectual and the country that receives him or her is capable of producing a double process of deprovincialization: those exiled end up displaced from their space of comfort, while the receiving country is introduced to different ways of thinking, as well as new modalities of knowledge. In the interaction, both sides become modified: the exiled person acquires new awareness through the effort to live in a foreign culture, while the culture acquires new horizons through this alien gaze. In the case of the relation between Stefan Zweig and Brazil, this process of mutual deprovincialization occurred while, having obtained his permanent visa in I94I, ${ }^{5}$ Zweig was still in Brazil for short periods only, just a few months. Even in these brief intervals of time, though, his contact with Brazil marked his thought and enabled him to rethink the European civilization in crisis via the horizon of possibilities open "under the Southern Cross," as he called it. Brazil, land of the future sought to insert Brazil in the cosmopolitan horizon, which he succeeded in doing as a result of the wide dissemination that the book received in its various language editions. What kind of exile is this? Did Zweig see Brazil as a homeland of refuge and potentially permanent stay or as one more place of displacement and travel? As Edward Said (I996) emphasized, exile can become a condition that is not only factual but also metaphoric for the intellectual, a kind of permanent displacement, maladjustment, an impossibility of belonging, which interposes a barrier and prevents the intellectual from ever arriving completely. The Brazilian exile of Zweig matches this model and rejects any possibility of assimilation: like a sort of permanent traveller between homelands and cultures. Given the loss of the European perspective as a horizon of completeness, Brazil constitutes, for Zweig, not a space of assimilation or belonging, nor a search for a return to the national perspective, but a point in a cosmopolitan passage that allowed him to open unprecedented cultural possibilities.

The maladjustment in response to the imperative of identity and the impossibility of belonging also determined Zweig's ambivalent relation to Juda- 
ism. Various critics have already highlighted his difficulty in identifying himself as Jewish and the hybrid, indefinite and ambivalent space occupied by him in relation to the Jewish identity. ${ }^{6}$ This is evident in his relationship with Theodor Herzl, founder of modern political Zionism and his literary mentor: Herzl was the first to support the young Zweig and offer him protection, allowing him to publish in the prestigious Feuilleton of the Neue Freie Presse, the supplement of which he was the editor (Zweig, 20I4b: 87). However, Zweig distanced himself from Herzl by refusing to participate actively in Zionism: "for me it was a grave decision to not associate myself actively and as a leader to his Zionist movement - which he perceived as ingratitude" (Zweig, 20I4b: 85-86). In contrast to Zweig, Herzl believed that the solution to the Jewish problem lay in the modern State and the idea of the nation as a symbolic system capable of agglutinating and organizing the population's energy (Schorske, I98I: 203-204). While Herzl affirmed the objective and function of a national solution to the Jewish question, Zweig, contrary to nationalism, constructed another horizon of possible solutions linked to cosmopolitanism - that is, to international agreements that presumed non-fixed and fluid ethnic and national identities. In I938, Zweig travelled to Portugal to propose that the territory of Angola, a Portuguese colony at the time, take in European refugees persecuted by Nazism, notably the Jews (Garcia Jr., 20II: I23; Dines, 2004). In this sense, Brazil had signified for Zweig a new possibility for achieving the project initially conceived for the Portuguese colonies in Africa: obtain approval from the political authorities for the mass immigration of European refugees (Garcia Jr., 20I I: I 27). Although the book makes no explicit mention of this possibility, it emphasizes the role of converted Jews in the settling of Brazil at the time of conquest:

\begin{abstract}
The only colonists who arrive of their own accord, not from chains, and without brands or verdict of the judge, are the Cristãos novos, the newly baptized Jews. But even these do not come entirely of their own free will, but from precaution and fear. They have taken the baptism in Portugal more or less sincerely to avoid the stake, but quite naturally they no longer feel safe in the shadow of Torquemada. It seems wiser to move on to a new country in time, so long as the grim hand of the Inquisition has not yet reached across the ocean. Forming groups, these baptized and unbaptized Jews settle down in the ports as the first real civilian colonizers. These Cristãos novos are destined to become the oldest families of Bahia and Pernambuco, and incidentally the first organizers of trade (Zweig, I94I: 53).
\end{abstract}

These converted Jews who arrived from the sixteenth century are, for Zweig, the model colonizer; they had laid the foundations of modern Brazil. Like the European refugees of the twentieth century, their immigration to Brazil represented a flight from persecution by authoritarian systems of government: indeed they had been forced to change identity, unable to stay in their territory of origin without the risk of being deprived of their citizenship. However, from Zweig's viewpoint, these immigrant Jews of the sixteenth century 
had been capable of contributing to the country through their bourgeois condition, their capacity to organize trade and their "knowledge of the world market" (Zweig, I94I: 24). In this sense, they too were similar to the European refugees of the twentieth century who, from Zweig's Eurocentric viewpoint, could contribute with immigrant labour, science and technology to the productivity of a country that he perceived as terra incognita, a virgin territory still waiting to be explored (Garcia Jr., 20I I: I 27).

It is important to stress, however, that the text not only reproduces a Eurocentric view of Brazil: it also questions and denounces it. One of the topics that permeates the book, linked to the displacement and deprovincialization it undertakes, are European and North American preconceptions about Brazilian culture. Already in the introduction, Zweig reflects on his ideas prior to the voyage, which he considers paradigmatic of the mentality of the European and North American tourist, and describes the exotic image that they have of Brazil:

My ideas of Brazil coincided with those of the average European and North American. It is only with an effort that I can reconstruct them today: it was very difficult to distinguish any one of these South American republics from the other; they all had a hot and unhealthy climate, political unrest, and desperate financial conditions; they were badly governed, and semi-civilized, and only near the coastal cities. At the same time the scenery was beautiful and there were numerous unexplored possibilities - in short, a land for desperate immigrants and settlers, but never one from which to expect intellectual stimulation. Being neither a professional geographer, collector of butterflies, sportsman, nor businessman, I presumed that a visit of ten days would suffice. A week, ten days, then back again, I thought; and I am not ashamed to confess to this naive attitude of mine. I even consider it important, for this is the prevalent idea shared today by most Europeans and North Americans. From the cultural point of view Brazil is still as much the terra incognita as it was for the first seafaring men from the geographical point of view (Zweig, I94I: 2-3).

The text calls attention to the Eurocentric imaginary of Brazil, which in some respects echoes the orientalist and exotic ideology that Edward Said analysed in his book Orientalism (1978) - in which the colonized nations are associated with backwardness, lack of preparation and the impossibility of self-governance ${ }^{7}$ - but applied to South America: the unhealthiness, the supposed incapacity to govern, the absence of their own forms of culture and civilization, the abundance of the natural environment. Zweig places in question this view, which associates Brazil with adventure, the search for easy wealth, the desire for conquest: in this view, the peripheral country is pure matter, incapable of self-governance, unable to produce its own culture, given its supposed lack of any "stimulus for the spirit."

In contrast to the Eurocentric view, imbued with a sense of superiority that Zweig calls a "presumption of superiority in civilization," a gaze that observes "from the hotel and the automobile," based on the premise that little effort or time would be needed to know Brazil, over the course of the book Zweig 
emphasizes the insufficiency of his own knowledge about the country and how the vastness and complexity of the territory and Brazilian cultures challenge the foreigner's gaze. Thus, he spends various paragraphs narrating what he has not visited, what he does not know, and what he cannot say about Brazil, highlighting the incompleteness of his viewpoint and the immensity of the country: "I know that this picture is not, cannot be, complete. It is impossible to know Brazil, a world in itself, completely. [...] in spite of all my eagerness to learn and constant travelling, my survey fails to be comprehensive; and I realize also that a whole life-time would not give one the right to say: I know Brazil" (Zweig, I94I: I2-I3). Paradoxically, in reflecting on the Eurocentric perspective, he himself repeats new stereotypes about Brazil and its nature, as an unexplored country, immense, which the human will to explore and know could never fully encompass.

\section{BRAZIL, A COSMOPOLITAN CULTURAL EXPERIENCE}

However, Zweig's thought concerning Brazil experiences another profound displacement. Even when he engages in generalizing, Eurocentric and ethnocentric affirmations, ${ }^{8}$ his viewpoint is doubly deprovincialized: it distances itself from the culture of origin through the loss of Austrian citizenship and the need to rethink, in the face of Nazism, the premises on which European culture rested - in which "the value of the words 'civilization' and 'culture' cease to be equivalent to 'organisation' and 'comfort' (Zweig, I94I: I9) - but it also resists as similation into the cultures that provided him with refuge and citizenship: British, North American and Brazilian. As he declares in his autobiography: "I don't belong anywhere, everywhere I am a foreigner or in the best of hypotheses a guest; the very homeland that my heart had chosen for itself, Europe, has become lost to me ever since it started tearing itself apart for the second time in an internecine war" (Zweig, 20I4b: I0). He describes Brazil from the perspective of a multiple deprovincialization, comparing and contrasting it with Europe and the United States - Rio de Janeiro with New York or Paris, São Paulo with Manchester or Liverpool - always speaking of distinct societies and national cultures from a certain distance. Brazil, land of the future indeed constructs a distanced viewpoint of Brazil - we can recall that the original title of the text was "Looking at Brazil" - like looking at it from afar, from an airplane - as revealed by the chapter titles "The flight over the North" and "The flight to the Amazon." This is a mobile perspective, in transit, which is evident in the very short final chapter, "Farewell," in which Zweig finds himself in the airport, heading to the United States, which calls attention to the ephemerality of his Brazilian experience.

Brazil, land of the future should be conceived as, at the same time, an interpretation of Brazil, a text on exile and a piece of travel writing. It comprises an expanded notion of travel: to travel through the book is simultane- 
ously research and knowledge, as well as exile, the search for a homeland, even if it is ephemeral or temporary. The tension between the tourist experience, the search for knowledge and refuge pervade the text: Zweig is a tourist, an adventurer in search of new experiences and knowledge, but also someone stateless. As a tourist, he wanders through the streets of Rio de Janeiro, Copacabana beach and the favelas and - as in the travel reports of colonial discovery about which he himself wrote - he judges what he sees in comparison with its European or, in some cases, North American equivalent. As he states in the chapter "Rio de Janeiro: art of contrasts":

In an hour or two one has driven through not only a city, but a world - to stand still finally, slightly giddy, amidst this colourful tumult of people and shops. One of these southern streets reminds one of the Cannebière in Marseille, another of Naples, the thousand cafés with their chattering men of Barcelona or Rome, the cinemas with their signs and the skyscrapers of New York. One is everywhere at the same time; and by this unique combination one knows this is Rio (Zweig, I94I: I73).

From the perspective of Zweig the tourist, Rio de Janeiro ends up deprovincialized, becoming comparable and equivalent to various cities around the world, Marseilles, Naples, Barcelona, Rome and New York, as a cosmopolitan territory in itself, not "a city" but "a world," seen on the international horizon. Likewise, his visit to a coffee plantation and his trip by airplane to the Amazon remind him of the German adventure and travel books he read in adolescence and childhood:

Ever since childhood days - since the first time one read how Orellana travelled in his tiny canoe down this river, accomplishing the most remarkable of all journeys; [...] one had been dreaming of a glimpse of this mighty river, the Amazon. And now, here one is at its mouth - or rather at one of its mouths, each of which is more enormous than that of any European river (Zweig, I94I: 299).

His imagination reprises the European gaze on Brazil and its literature of adventures and voyages, but goes beyond, given that the Amazon is greater than "any European river." Through his cosmopolitan gaze, Zweig deprovincializes Brazil, placing it on the global horizon.

On the other hand, more than as a tourist trip, the book narrates the journey as a profound quest that forges a unique perspective with the help of a geographical movement but also an epistemological movement. As Fernanda Peixoto (20I5: I4) studied in her book A viagem como vocação (Travel as vocation), the modern journey relaunches the idea of travel as personal development, heir to the German notion of Bildung, as a practice defined by the experience of alterity, whose essence is to locate the 'self' in a movement that turns it into an 'other'. As he states in his 1936 conference in Rio de Janeiro "The spiritual unity of the world" - which he repeated in São Paulo, Córdoba, Mendoza and Montevideo in I 940 - the "young peoples" "of the South" had the capacity to 
overcome the nationalism that threatened to destroy Europe and go beyond the sectarianism and small-mindedness that "limits comradeship to one's own circle, one's own country" and hates the 'foreigner' (Zweig, 20I4a, p. 59). They were capable of moving towards the "unity of humanity," which transforms the world and develops it in another direction. Zweig's words reveal the intention to question the Eurocentric perspective in the face of the crisis of European values and the will to conceive an idea of 'world' - note that the original title of the text in French was "The spiritual unity of Europe," which he changes soon after his lecture in Rio de Janeiro to "The spiritual unity of the world" (Zweig, 20I4: 69) - which would set out from South America and its 'youth' as a space of potentiality.

These reflections are continued in Brazil, land of the future. In the preface by Afrânio Peixoto that appeared in the book's first edition - and that so harmed its reception at the time among the local intellectual circles - Peixoto calls Zweig "our guest" and describes the book as the product of the "love of a supercivilized caboclo: the girlfriend will know now and will be confused by such goodwill. But he has already left" (Zweig, I94I: 7). 9 According to Afrânio Peixoto, the book was the outcome of Zweig's passion for Brazil, which had not been successful, resulting in a failed encounter. Peixoto refers to Zweig's hybrid condition, miscegenated, a 'supercivilized' European but at the same time Jewish outcast, without a homeland or a place of belonging, which signals the ambivalence that he represented for the Brazilian intellectual environment of the period. He was a successful and globally recognized European writer but, at the same time, a refugee, someone who arrived begging - to use Hannah Arendt's word - to Brazil for citizenship. A difficult subject to classify, to fit into any taxonomy, in various points similar to the figure of the Marrano, the converted Jew who, for Zweig, was the model colonizer, who had laid the foundations of modern Brazil. The Marrano is the other, a mestiço who, like Zweig, refuses the logic of identity - whether the Jewish identity or any national identity - and points to a type of incomplete and fractured subjectivity, which deconstructs the hierarchy between religions and nationalities and between citizens and those excluded from citizenship. Marrano subjectivity resides in the breakage, in the splitting of identities. ${ }^{\text {Io }}$

Brazil is a space of learning and transformation for the 'supercivilized' European, a space of potentiality. These are the lines along which we should read his claim that it was during his voyage through South America that he had "begun [...] no longer to think on the scale of Europe, but also the rest of the world - not bury oneself in a moribund past but participate in its rebirth" (Zweig, 20I4b: 295). On his trip to Buenos Aires and "under the Southern Cross" he had started to imagine this 'rebirth' in a cosmopolitan sense, and relativize the protagonism of a Europe in crisis. Similarly, on the trip to Brazil, he perceived that there was "space for the future in an incommensurable abundance, while 
in Europe the nations fought and the politicians disputed the most miserable scraps" (Zweig, 20I4b: 296). Brazil appears as pure potency, even from a perspective pervaded by stereotypes.

\section{FINAL CONSIDERATIONS}

As an exiled man, a pacifist, intellectual and anti-totalitarian writer; as a Jew, a man with no homeland, persecuted, internationalist and cosmopolitan, Zweig marks a series of possible pathways to think about the world. Through the rise of Nazism, Zweig became a "foreigner," a perpetual "guest," someone stateless, as he himself stated in his The world of yesterday: an autobiography. He reflected, then, on the relevance of internationalism and cosmopolitan thought in the Jewish tradition. After his arrival in Brazil he became an interpreter of the country and a thinker on its racial, religious and cultural diversity, as apparent in Brazil, land of the future.

In this article, we have sought to present some of the connections between Brazil, land of the future and Brazilian social thought, and suggest a possible dialogue with the United States and Europe in terms of anti-racist agendas in a kind of triangular play of mirrors. We analysed Zweig's voyage to Brazil as a search for a renewed comprehension of the cosmopolitan "unity" of the world seen from the South.

Zweig belongs to a group of Jewish intellectuals who set their sights on Brazil. In seeking to deracialize the country, they invested in the deracialization of Jews (Benedicty-Kokken, 20I6). Alongside Zweig were Melville Herskovits, Ruth Landes, Marvin Harris, Benjamin Zimmerman, Otto Klineberg, Levi-Strauss and Alfred Métraux, among others.

Brazil, land of the future is a book about exile, at once a travel report, a tourist trip and an exploration of otherness. A Eurocentric text that questions Eurocentrism, an interpretation of Brazil that combines bewilderment and fascination, cultural alterity and cosmopolitanism. By emphasizing the deep ambivalence of the text and the author himself, difficult to classify and fit into any fixed taxonomy or identity - religious, national, cultural, racial or discursive - we have sought to rethink some of the dilemmas of cosmopolitanism in the twentieth century. 
Alejandra Josiowicz is Master and PhD in Spanish and Portuguese, Princeton University (PU). She is currently researcher at the National

Council for Science and Technological Research of Argentina (CONICET) and Postdoctoral Fellow at the School of Social Sciences of the Getulio Vargas Foundation (CPDOC-FGV) in Brazil. Prof. Josiowicz has published La Cruzada de los niños. Intelectuales, infancia y modernidad literaria en América Latina (Universidad Nacional de Quilmes, 2018), as well as articles in the Journal of Lusophone Studies, Lua Nova and others.

Marcos Chor Maio is researcher and professor of Graduate Program on History of Sciences and Health, Oswaldo Cruz Foundation. He received his Master and $\mathrm{PhD}$ in Political Science from the Instituto Universitário de Pesquisas do Rio de Janeiro (IUPERJ) and has been a visiting scholar at the Department of History/NYU. Prof. Maio is the author of Nem Rothschild, nem Trostky: o pensamento anti-semita de Gustavo Barroso; co-editor of Raça, ciência e sociedade and Raça como questão: história, ciência e identidades no Brasil. Currently he is studying the relationship between social psychology, sociology and anthropology on the studies of race and racism in Brazil and United States (I940-1960). 


\section{NOTES}

I A previous version of this article was presented in the "Why Stefan Zweig?" Debate Series, held in June 2017 at the Midrash Cultural Centre (Rio de Janeiro) and in July 2017 at the 2nd Symposium of the Southern Cone Section of the Latin American Studies Association (Montevideo).

2 The title of the first edition of Stefan Zweig's book in Portuguese (I94I), Brasil, país do futuro matches the title published in English: Brazil, land of the future. However, the second edition (2006) was a direct translation from the German: Brasilien, ein land der Zukunft (Brasil, um país do futuro), Brazil, a land of the future. The German title removes Brazil's exceptionality. For a wider analysis of the diverse titles of the editions translated from German, see Dines, 2004.

3 In the interval between the I920s and I940s, essays were published that became classics, seeking to make intelligible the formational process of Brazilian society, combined with diverse readings of the national identity. These included: Populações meridionais do Brasil (Oliveira Vianna, I920), Retrato do Brasil (Paulo Prado, I928), Casagrande \& senzala (Gilberto Freyre, I933), Evolução política do Brasil (Caio Prado Jr., I933), Raízes do Brasil (Sérgio Buarque de Holanda, I936), Sobrados e mocambos (Gilberto Freyre, I936), and Formação do Brasil contemporâneo (Caio Prado Junior, 1942). Exploring the relations between essayism and the social sciences, Botelho (2010) proposes a problematization of the recurrent tendency in the literature on the theme to approach the essays in a univocal form.

4 On this theme, see Zweig and Zweig (20I2: I82, I83, I86, I89).

5 The concept of 'deprovincialization' is based on the historiographic project of postcolonial studies of relativizing the universalism implicit in the human sciences forged in eighteenth-century Europe. Dipesh Chakrabarty (2000), in his Provincializing Europe, for example, proposes to move beyond Eurocentric history, signalling the limits to its social and political categories and seeing colonial societies as central elements of modernity, capable of placing the metropolitan identity itself under question. 
6 On his difficulty in identifying himself as Jewish, or with any nationalist or Zionist ideology, see Spitzer (200I). Grin (2002) also emphasizes the ambivalent, indefinite and hybrid space occupied by Stefan Zweig.

7 For a critique of this imaginary from the perspective of postcolonial studies, see Chakrabarty (2000).

8 For a reading along these lines, see Karen Macknow Lisboa (2013).

9 The publication of Brazil, land of the future generated a series of controversies concerning the literary quality and political nature of the work. Dines (2004) conducted a series of interviews with writers who had lived during Zweig's period, demonstrating the critical distance between Brazilian intellectuals (Sérgio Buarque de Holanda, Gilberto Freyre, Carlos Drummond de Andrade and others) and the Austrian writer.

Io For a discussion of the Marrano and Marranism, see Erin Graff Zivin (20I4).

\section{BIBLIOGRAPHY}

Antelo, Raúl. (2009). O ensaio terminal. Essência como potência. Escritos II, p. I87-2I2.

Araújo, Ricardo Benzaquen. (I994). Guerra e paz: Casa-grande \& senzala e a obra de Gilberto Freyre nos anos 30. Rio de Janeiro: Editora 34.

Arendt, Hannah. (2007). Stefan Zweig: Jews in the world of yesterday. In: Reflections on literature and culture. Stanford: Stanford University Press, p. 58-68.

Azevedo, Thales. (1955). As elites de cor: um estudo de ascensão social. São Paulo: Companhia Editora Nacional.

Benedicty-Kokken, Alessandra. (2016). On 'being Jewish', on 'studying Haiti' ... Herskovits, Métraux, race and human rights. In: Benedicty-Kokken, Alessandra et al. (eds). The Haiti exception: anthropology and the predicaments of narrative. Liverpool: Liverpool University Press.

Botelho, André. (2010). Passado e futuro das interpretações do país. Tempo Social, 22/I, p. 47-66. 
Burke, Peter. (2017). Exiles and expatriates in the history of knowledge, I500-2000. Waltham: Brandeis University Press. Carvalho, José Murilo de. (I998). O motivo edênico no imaginário social brasileiro. Revista Brasileira de Ciências Sociais, 13/38, p. 19-38.

Chakrabarty, Dipesh. (2000). Provincializing Europe. Postcolonial thought and historical difference. Princeton: Princeton University Press.

Dines, Alberto. (2004). Morte no paraíso. A tragédia de Stefan Zweig. Rio de Janeiro: Rocco.

Fontanals Garcia, David. (2013) La historia de una utopía fallida. Proyectando una Europa cosmopolita y sin fronteras en El mundo de ayer: memorias de un europeo, de Stefan Zweig. Tesis de Maestría. Universidad de Barcelona.

Frazier, Franklin. (1942). The negro family in Bahia, Brazil. American Sociological Review, 7/4, p. 465-478.

Freyre, Gilberto. (I933). Casa-grande \& senzala. Rio de Janeiro: Editora Maia \& Schmidt.

Garcia Jr., Afrânio Raul. (20II). Les souvenirs d'un européen: entre le Brésil, Terre d'Avenir et Le Monde d'Hier. Actes de la Recherche en Sciences Sociales, I/I86-I87, p. II2I3I.

Grin, Mónica. (2002). Modernidade, identidade e suicídio: o "judeu" Stefan Zweig e o "mulato" Eduardo de Oliveira e Oliveira. Topoi, 3/5, p. 20I-220.

Guerreiro Ramos, Alberto. (I954). O problema do negro na sociologia brasileira. Cadernos do Nosso Tempo, 2, p. I89230.

Hellwig, David. (1992). African-American reflections on Brazil's racial paradise. Philadelphia: Temple University.

Krebs, Edgardo C. (20I6). Popularizing anthropology, combating racism: Alfred Métraux at The Unesco Courier. In: Duedahl, Poul (ed.). A history of Unesco: global actions and impacts. London: Palgrave/Macmillan.

Lisboa, Karen Macknow. (20I4). Entre o passado europeu e o futuro americano: dois ensaios sobre o Brasil da década de 1930. História, Ciências, Saúde - Manguinhos, 2I/I, p. 317-332. 
Lisboa, Karen Macknow. (20II). Mundo novo, mesmo mundo: viajantes de língua alemã no Brasil (1893-1942). São Paulo: Fapesp/Hucitec.

Maio, Marcos Chor. (I999a). Estoque semita: a presença dos judeus em Casa-grande \& senzala. Luso-Brazilian Review, 36/I, p. 95-IIO.

Maio, Marcos Chor. (I999b). O projeto Unesco e a agenda das ciências sociais no Brasil dos anos 40 e 50 . Revista Brasileira de Ciências Sociais, I4/4I, p. I4I-I58.

Maio, Marcos Chor \& Lopes, Thiago da Costa. (2017). Entre Chicago e Salvador: Donald Pierson e o estudo das relações raciais. Estudos Históricos, 30/60, p. II5-I40.

Métraux, Alfred. (I95I). Brazil: land of harmony for all races?. Courier, 4/4, p. 3.

Oliveira Vianna, Francisco José. (1959) [I932]. Raça e assimilação. 4 ed. Rio de Janeiro: José Olympio, I959.

Palhares-Burke, Maria Lúcia. (20I2). O triunfo do fracasso. Rüdiger Bilden, o amigo esquecido de Gilberto Freyre. São Paulo: Edusp.

Peixoto, Fernanda A. (20I5). A viagem como vocação. Itinerários, parcerias e formas de conhecimento. São Paulo: Edusp. Pesavento, Sandra. (200I). Stefan Zweig: uma janela para a história. In: Chiappini, Lígia; Dimas, Antonio \& Zelly, Berthold (org.). Brasil, país do passado? São Paulo: Editora Boitempo, p. 59-65.

Ramos, Jair de Souza. (2003). Ciência e racismo: uma leitura crítica de Raça e assimilação em Oliveira Vianna. História, Ciências, Saúde, Manguinhos, Io/2, p. 573-60I.

Robbins, Bruce \& Horta, Paulo Lemos (eds.). (2017). Cosmopolitanisms. New York: New York University Press.

Roquette-Pinto, Edgard. (I929). Notas sobre os typos anthropológicos do Brasil. Actas e trabalhos do primeiro Congresso Brasileiro de Eugenia. Rio de Janeiro, p. II9-I47.

Said, Edward. (I996). Intellectual exile: expatriates and marginals. In: Representations of the Intellectual. New York: Vintage Books.

Sansone, Livio. (20II). Turner, Franklin and Herskovits in the Gantois House of Candomblé: the transnational origin of Afro-Brazilian studies. The Black Scholar, 4I/I, p. 48-63. 
Schorske, Carl E. (I98I). Fin-de-siècle Vienna. Politics and culture. New York: Vintage Books.

Skidmore, Thomas E. (I993) [I974]. Black into white: race and nationality in Brazilian thought. Durham: Duke University Press.

Spitzer, Leo. (200I). Vidas de entremeio. Assimilação e marginalização na Áustria, no Brasil e na África Ocidental, I780I945. Rio de Janeiro: Eduerj.

Valladares, Licia do Prado. (20I0). A visita do Robert Park ao Brasil, o "homem marginal" e a Bahia como laboratório. Cadernos CRH, 23/58, p. 35-49.

Zivin, Erin Graff. (2014). Figurative inquisitions. Conversion, torture and truth in the Luso-Hispanic Atlantic. Chicago: Northwestern University Press.

Zweig, Stefan. (2014a). A unidade espiritual do mundo. Rio de Janeiro: Ed. Zahar.

Zweig, Stefan. (20I4b) [1942]. Autobiografia: o mundo de ontem. Rio de Janeiro: Ed. Zahar.

Zweig, Stefan. (I94I). Brasil, país do futuro. Trad. Odilon Gallotti. Rio de Janeiro: Ed. Guanabara.

Zweig, Stefan \& Zweig, Lotte. (2012). Cartas da América. Rio, Buenos Aires e Nova York, I940-I942. Introdução e organização de Darién Davis e Oliver Marshall. Trad. Eduardo Silva e Graça Salgado. Rio de Janeiro: Versal. 


\section{STEFAN ZWEIG E O EXÍLIO: INTERPRETAÇÕES DO BRASIL DE UM CIDADÃO COSMOPOLITA} Resumo

Este artigo tem por objetivo analisar Brasil, país do futuro, de Stefan Zweig, destacando os nexos que ligam essa obra, a um só tempo, aos contextos intelectuais brasileiro, norte-americano e europeu, assim como à escrita sobre o exílio, sobre a viagem e sobre o cosmopolitismo. O livro diz respeito a um diálogo tenso e cheio de desencontros entre Zweig e o meio brasileiro: entre o horizonte cosmopolita e multilíngue do autor, sua impossibilidade de pertencer e seu permanente desajustamento. Concebemos ainda Brasil, país do futuro como mais um manifesto da agenda antirracista dos anos I930 e I940, fruto dos diálogos cruzados que não se limitam ao pensamento sobre o Brasil, mas a uma pauta intelectual e política internacional em permanente discussão e circulação nos Estados Unidos e na Europa, e que tinha no Brasil uma espécie de campo de experimentação, de certificação, de positivação das relações humanas.

\section{STEFAN ZWEIG IN EXILE: A COSMOPOLITAN CITIZEN'S INTERPRETATION OF BRAZIL}

Abstract

This article sets out to analyse Brazil, land of the future, by Stefan Zweig, highlighting the links that connect the book to the Brazilian, North American and European intellectual contexts, as well as to travel writing, exile and cosmopolitanism. Brazil, land of the future contains a tense dialogue, full of failed encounters, between Zweig and the Brazilian milieu: between the author's cosmopolitan and multilingual horizon, the impossibility of belonging and his constant feeling of maladjustment. We examine Brazil, land of the future as another manifesto of the I930s and I940s anti-racist agenda, the product of cross-dialogues that were not limited to the social reflection on Brazil, but encompassed an international intellectual and political agenda that was continually discussed and disseminated in the United States and Europe and that approached Brazil as a field for experimenting, certifying and positivizing human relations.
Palavras-chave

Stefan Zweig;

pensamento social no Brasil; identidade judaica; exílio; cosmopolitismo.

\section{Keywords}

Stefan Zweig;

Jewish identity; intellectual history; exile; cosmopolitanism. 